\title{
Estudo sobre comunicação organizacional em emprestas belorizontinas: discurso para públicos ou diálogo com stakeholders?
}

\section{Wilma Pereira Tinoco Vilaça}

- Doutoranda do programa de Ciências da Comunicação da Escola de Comunicações e Artes da Universidade de São Paulo (ECA-USP)

- Mestre em Administração, com ênfase em Gestão e Inovação, pela Pontifícia Universidade Católica (PUC-Minas) em parceria com a FDC

- Especialista em Comunicação e Gestão Empresarial, pelo IEC-PUC

- Graduada em Comunicação Social (Relações Públicas), pela FAFI-BH (UNI-BH)

- Coordenadora do curso de Especialização em Comunicação Empresarial, Latu Senso do Centro Universitário de Belo Horizonte (UNI-BH), onde também atua como docente

- Professora-convidada do Programa de Pós-Graduação do Centro Universitário Newton Paiva, no MBA de Gestão Estratégica de Empresas

- Professora-convidada Programa de Pós-Graduação do Instituto de Educação Continuada, da PUC-Minas, nos cursos de Gestão de Eventos e Gestão da Marca e da Identidade Corporativa

- Pesquisadora e Supervisora da Agência de Relações Públicas (AGERP) do UNI-BH

- wilma.vilaca@gmail.com 
Este trabalho apresenta pesquisa realizada em 2007, no UNI-BH, com o objetivo de melhor compreender as características da comunicação das organizações. Empiricamente, buscou-se conhecer como e com quais objetivos empresas localizadas em Belo Horizonte, trabalhariam seus processos comunicacionais. Os resultados confirmam que, embora os discursos apontem para uma comunicação mais dialógica e participativa, as práticas continuariam prescrevendo velhas fórmulas em que se configuraria uma comunicação muito linear, com menor ênfase nas possibilidades de efetiva intervenção na realidade dos envolvidos.

PALAVRAS-CHAVE: COMUNICAÇÃO ORGANIZACIONAL • DISCURSO • DIÁLOGO • STAKEHOLDERS

Abstract

This work presents research conducted in 2007 at UNI-BH, with the purpose of having a better understanding of the characteristics of organizational communication. Empirically, it aimed at identifying how and with what purposes would companies established in Belo Horizonte develop their communication processes. The results confirmed that, although the discourses point to more dialogic and participative communication, the practices continue to prescribe old formulae through which a very linear communication is characterized, with less emphasis on the possibilities of effective intervention in the reality of those involved in the communication process.

KEYWORDS: ORGANIZATIONAL COMMUNICATION • DISCOURSE • DIALOGUE • STAKEHOLDERS

Resumen

Se presenta una investigación realizada en 2007 en la UNI-BH, con el fin de comprender mejor las características de la comunicación en las organizaciones. Empíricamente se buscó conocer cómo y con qué objetivos las empresas ubicadas en Belo Horizonte trabajarían sus procesos de comunicación. Los resultados confirman que, aunque los discursos apunten a una comunicación más dialógica y participativa, las viejas prácticas continúan prescribiendo fórmulas, que establecieron una comunicación muy lineal, con menos énfasis en las posibilidades para una intervención efectiva en la realidad de las personas involucradas.

PALABRAS CLAVE: COMUNICACIÓN ORGANIZACIONAL・DISCURSO • DIÁLOGO • STAKEHOLDERS 
0 presente artigo tem como elemento fundante as frequentes discussões em fóruns da área de Comunicação e, especificamente, nos fóruns privilegiados das Relações Públicas, sobre a delimitação epistemológica do campo da comunicação, alicerçada sobre os estudos recentes de Kunsch (2006), Braga (2001, 2004), Reis (2006), Curvello (2002), Oliveira e Paula (2007) e Soares (2006). Tais estudos, grosso modo, buscavam pautar-se em abordagens mais contemporâneas, que permitissem avanços nas reflexões teóricas até então disponíveis, embora também ensejassem a percepção de que seria possível estabelecer um ponto de confluência em todos eles: a comunicação, comumente definida como um campo de interfaces, em que diversas áreas de conhecimento se imbricam, encontrou locus privilegiado no cenário organizacional contemporâneo, em que se evidenciam, cada vez mais, a complexidade e a necessidade de se reconstruírem sentidos e práticas, permitindo uma abordagem mais interpretativa da realidade organizacional.

Nesse sentido, as organizações seriam vistas como realidades socialmente construídas, nas quais o papel da comunicação teria que ser discutido à luz da compreensão de que sua importância só poderia ser determinada conforme a estrutura da organização - o que nos permitiria dizer que essa importância tenderia a ser relativizada [ou não] “(...) conforme o lugar para onde se olhe numa organização e conforme o tipo de organização que esteja sendo estudada” (HALL, 1984, p. 132).

A partir dessa constatação, observa-se que o cenário dado às organizações - a globalização, a volatilização das fronteiras, a reconstrução geopolítica do mapa internacional, a liberdade democrática, a noção da cidadania e o reconhecimento do espaço público como esfera da igualdade, bem como os avanços das tecnologias de informação -, paradoxalmente, contribui também para deixar expostas suas fragilidades internas: a recuperação da individualidade que revela a ambiguidade do mundo moderno.

Dessa maneira, ao compreender que “(...) para além de qualquer tipo de isolamento, a possibilidade real de acesso à individualidade reside na presença da alteridade" (RUCHEINSKY, 1999, p. 38), indivíduos e empresas descobrem que o elemento basilar da dinâmica organizacional estaria na observância do outro e começam a vivenciar um processo que encontra ressonância pela via da comunicação. No entanto, Wolton (2006) advoga que informar não seria condição para que houvesse, a priori, a comunicação.

O que se percebe é que, embora o discurso organizacional induza à ideia de que as pessoas seriam um ativo estratégico e, em nome delas, os esforços comunicacionais estariam sendo envidados, a questão que se coloca é que diferentes, complexas, ambíguas e contraditórias formas de comunicação são tecidas nas e pelas empresas atuais.

Nesse sentido, este trabalho teve, como pergunta orientadora, a seguinte ques- 
tão: - Tendo em vista as mudanças no cenário empresarial contemporâneo, quais desafios a comunicação organizacional enfrentaria para dissociar-se do paradigma instrumental tradicional e adotar uma perspectiva mais participativa na sua tomada de decisões? Para tanto, o presente texto estrutura-se da seguinte forma: uma primeira parte, em que são apresentados os conceitos de comunicação organizacional; a segunda em que se busca estabelecer fronteiras entre o que se convencionou chamar de discurso e diálogo; a terceira que traz os resultados da pesquisa empírica e, por fim, as conclusões, nas quais se compartilham reflexões e se divide o alcance das descobertas.

\section{Comunicação organizacional}

Este artigo, conforme delineado em sua introdução, parte do atual debate entre pesquisadores brasileiros sobre comunicação organizacional, cujo cerne das discussões adota a década de 1990 como cenário de mudanças conceituais paradigmáticas e que conferem à comunicação organizacional uma dimensão muito mais relacional que informacional. É nessa época, por exemplo, que surge o modelo de comunicação integrada desenvolvido, aperfeiçoado e tornado referência por Kunsch (1986). Esse modelo preconizava a junção de diversos tipos de comunicação existentes na organização, permitindo uma atuação mais sinérgica da mesma e pautou o trabalho de toda uma geração de profissionais, acadêmicos e estudantes, principalmente, os da área de relações públicas.

O modelo de comunicação integrada teve como ponto de partida a dissertação de mestrado de Kunsch (1986), defendida no final do ano de 1985, na Escola de Comunicação e Artes da Universidade de São Paulo, que resultou na publicação de um livro - referência para gerações de egressos - no qual a autora já postulava que "(...) não se pode mais isolar, por exemplo, a comunicação institucional e a comunicação mercadológica. É necessário que haja uma comunicação integrada (...)" (KUNSCH, 1986, p. 107). Levada a efeito e a partir de sua aplicação bem-sucedida por diversas grandes empresas, a comunicação integrada lança as bases para o que hoje se convencionou chamar de comunicação organizacional - aqui entendida como "(...) a disciplina que estuda como se processa o fenômeno comunicacional dentro das organizações no âmbito da sociedade global. Ela analisa o sistema, o funcionamento e o processo de comunicação entre a organização e seus diversos públicos” (KUNSCH, 2006, p. 185) - que permitiria uma visão não fragmentada da comunicação nas e das organizações.

Em 2002, as convergências encontradas com o modelo de comunicação integrada de Kunsch (1986) e o modelo de comunicação simétrica de mão dupla de Grunig (1992) foram também importantes referências para a defesa de tese de Oliveira (2002) que desenvolveu o modelo de interação comunicacional dialógica, apresentado como uma tentativa de oferecer elementos para sub- 
sidiar as discussões sobre os desafios enfrentados pela comunicação organizacional atualmente.

Obviamente que esse percurso, não cronológico e sabidamente lapso, é evocado somente como pano de fundo para a constatação de que, hodiernamente, as discussões teóricas sobre a constituição do campo da comunicação sempre a subordinam às demandas da administração, forçando a inquirir-se sobre qual outro olhar seria possível construir, que não aquele que tem colocado sempre a organização como principal interlocutor. De toda maneira, essa confluência possibilitou ajustar criticamente esse olhar. O que se advoga aqui é que esses modelos são importantes porque são capazes de demarcar uma ótica teórica para o campo da comunicação organizacional, retirando-lhe esse caráter de generalidade e contribuindo para que se aproxime da "(...) possibilidade de fundamentar um saber propriamente comunicacional” (MARTINO, 2004, p. 12).

Assim, a comunicação organizacional, que “(...) se processa nas interfaces com outros campos e promove interações entre organização e atores sociais, trabalhando os fluxos informacionais e relacionais, de modo a contribuir para a construção de sentido sobre as ações da organização e do ambiente" (OLIVEIRA; PAULA, 2007, p. 21), seria complexa, ambígua, dual, pois esse dar sentido sobre as ações das organizações passaria, naturalmente, pela questão cotidiana de experiências partilhadas, pela expressão e veiculação de mensagens e, sobretudo, pela sua recepção. Diversos autores se dedicam aos estudos da recepção (QUERÉ, 1991; HABERMAS, 1989; BRAGA, 2001), mas o que se pretende aqui é tentar analisar se a comunicação, nos moldes como ela é hoje teoricamente construída, não estaria baseada em uma capacidade hipostasiada de interlocução entre emissores e receptores. Ou seja, o que se busca, a partir dessa reflexão, e tendo como premissa que a comunicação é uma competência social, que liga seres humanos díspares, é entender como as organizações definem seu lugar de fala com seus stakeholders. Para tanto, uma breve conceituação de discurso e diálogo se faz necessária.

\section{Discurso e diálogo: faces de uma mesma moeda?}

O discurso organizacional tem sido visto, consensualmente, como uma forma de moldar, por meio das informações difundidas, a visão das pessoas sobre a organização. Para Girardi (2003, p.10),

"as relações institucionais se expressam no contrato que se estabelece entre quem fala/escreve e aquele que ouve/lê. Tais relações se inscrevem num contexto de regras estratégicas conhecidas e respeitadas pelos parceiros do jogo verbal que se atribuem papéis e decidem como organizar seus discursos em função dos enunciados produzidos / a produzir no tempo e local definido por eles".

Assim, parece claro que, por meio do discurso expresso em suas comunicações formais, principalmente as impressas, as organizações criariam seus textos tendo como referência os efeitos desejados em seu receptor. Os recursos 
da linguagem são utilizados como demarcatórios de diferentes práticas sociais, mas primam pela retórica e argumentação, porque precisam fazer com que as pessoas se convençam, acreditem naquilo que está sendo dito. $\mathrm{Na}$ arena discursiva, é importante adequar o que está sendo dito àquilo que pode contribuir para orientar melhor os sentidos no locus organizacional. Segundo Paulino (2003, p. 7),

"as cadeias discursivas que se estabelecem são plataformas que, reorganizadas (linguagem como ação) a partir da lógica do mundo do trabalho, são dirigidas por interesses, estratégias, planejamentos orientados em sua base pela natureza do trabalho (...) num movimento dialético que busca construir hegemonia."

Ainda, segundo a autora supracitada, diversas palavras foram suprimidas do idioleto organizacional, como se por meio da supressão estivéssemos livres da carga ideológica que as ata - ela cita, por exemplo, empregado, demissão, mandar embora e revela: "(...) hoje, as empresas passam por reestruturação e os colaboradores deixam de fazer parte da equipe” (PAULINO, 2003, p. 7, grifo nosso).

Nassar (s.d., p.34-35) também aponta nessa direção ao afirmar que

“(...) brincar, conversar ('trocar versos'), dialogar, debater, aprender, dividir e compartilhar não são os verbos da empresa, cuja administração e arquitetura são estruturadas apenas para somar. Nessa perspectiva de produção e de tempo mecanicista, coercitivo, homogêneo e sem surpresas, o verdadeiro processo comunicativo, que é um jogo democrático, em que todos (emissor/receptor) trocam de papéis, o tempo todo, não tem lugar".

O discurso teria, então, uma natureza muito mais informativa, de busca pela aquiescência do receptor e se distanciaria, por sua própria ontologia, do que seria uma abordagem dialógica, vista como aquela capaz de criar pontes com o receptor.

Para Bohm (2005), o diálogo somente seria possível quando aqueles que o vivenciassem conseguissem ir além dos pressupostos arraigados em pensamentos nos quais estariam presentes opiniões que foram forjadas por experiências anteriores, que perpassam nossa visão do mundo, das pessoas, as formas pelas quais nos relacionamos, trabalhamos, utilizamos nossa linguagem.

A palavra diálogo, de origem grega (dia - por meio de; logos - palavra), quer dizer por meio da palavra. Seu significado, porém, extrapolaria a etimologia para se traduzir, segundo Bohm (2005, p. 34) em "(...) corrente de significados que flui entre nós e por nosso intermédio; que nos atravessa, enfim. Esse fato tornará possível o fluxo de significados na totalidade do grupo, e daí podem emergir compreensões novas", o que parece concernente com o postulado por Citelli (2004) ao dizer que os sujeitos se apropriariam de todas essas referências da experiência de sociabilidade para elaborar seus conceitos e opiniões. Dessa maneira, o termo diálogo não pode ser compreendido, de acordo com 
Citteli (2004, p. 54), “(...) como sinônimo de ajuste, entendimento ou acerto harmônico". Mas teria a ver, sobretudo, com "(...) uma instância que marca a própria composição dos sentidos” (CITELLI, 2004, p. 54).

Se os receptores já não podem ser considerados apáticos, se reagem ao que lhes é dado, se são capazes de interpretar e reelaborar o cotidiano e, tão mais significativo, redefinir, a partir de seu entendimento, as práticas sociais, poderse-ia afirmar que o lugar de chegada da comunicação desloca-se do emissor para o receptor. O que leva, sem sombra de dúvida, à reflexão sobre a comunicação produzida, se a que se transmite é a mesma que se recebe e, fundamentalmente, a lógica do profissional que a produz. Essa, talvez, possa ser a contribuição dos dados que serão apresentados na sequência.

\section{A metodologia e a investigação empírica}

Como filtro metodológico, definiu-se que seriam empresas de médio e/ou grande portes, preferencialmente privadas e que tivessem um setor de comunicação formalmente constituído. A classificação por tamanho baseou-se na praxe adotada, desde 1995, para identificação das empresas via Relações Anuais de Informações Sociais (RAIS), do Ministério do Trabalho, por meio do número de empregados por elas registrados. Tal prática é referendada pelo SEBRAE-MG e, por isso, serviu de recorte teórico para a delimitação do campo desta pesquisa, a saber:

\section{Quadro 1 - Caracterização das empresas}

\begin{tabular}{|c|c|c|}
\hline Área & Especificação & $\mathrm{N}^{0}$ de Empregados \\
\hline \multirow[t]{2}{*}{ Indústria } & Média & $100-499$ \\
\hline & Grande & 500 ou mais \\
\hline \multirow[t]{2}{*}{ Comércio/Serviços } & Média & $50-99$ \\
\hline & Grande & 100 ou mais \\
\hline
\end{tabular}

Fonte: elaborado pela autora

O problema da pesquisa pode ser traduzido pela hipótese de que haveria um hiato entre o discurso proposto pelas organizações, de que emissores e receptores gozem de igual importância, e a prática aplicada, em que a comunicação continuaria sendo utilizada de forma imperativa, como instrumento para perpetuação do poder. Nesse sentido, foi imperioso traçar o perfil do setor de comunicação, identificando sua estrutura, recursos disponíveis, nível de autonomia, se desempenha um papel estratégico ou instrumental etc. 
Para o levantamento de quantas e quais seriam as empresas selecionadas, utilizou-se como fonte de dados primários os assessores de comunicação de empresas de médio e grande porte na Grande Belo Horizonte e, como dados secundários, a listagem dessas empresas que figuraram no Guia Melhores e Maiores, da Revista Exame, nos anos de 2006 e 2007. Adotou-se, então, a técnica snow-ball, em que um entrevistado indicou outro potencial entrevistado, aumentando significativamente o universo amostral, totalizando 26 empresas. Outro filtro importante foi que tais empresas tivessem a área de comunicação formalmente constituída. A partir daí, o método de coleta de dados foi o de entrevistas pessoais, gravadas e posteriormente transcritas, realizadas no período entre 08 de outubro e 28 de novembro de 2007 . O instrumento foi semiestruturado - questões abertas e fechadas apresentadas na mesma ordem e com as mesmas opções de respostas a todos os respondentes, e não-disfarçado - e o entrevistado conheceu, desde o início, os propósitos da pesquisa.

Na apresentação dos relatos obtidos, no entanto, os respondentes tiveram sua identificação suprimida, optando-se por caracterizá-los por uma letra do alfabeto, a fim de resguardar a relação de confiança estabelecida, conforme se pode ver no quadro 2 . Ressalva-se também que, para este artigo, foram recortadas as perguntas e os relatos mais pertinentes.

\section{Quadro 2 - Caracterização dos respondentes}

\begin{tabular}{|c|c|c|c|c|c|c|}
\hline Codificação & Segmento & Área de Atuação & $\mathrm{N}^{0}$ funcionários & Tamanho & $\begin{array}{l}\text { Tempo de } \\
\text { atuação }\end{array}$ & $\begin{array}{c}\text { Estrutura } \\
\text { política alegada }\end{array}$ \\
\hline A & Outros & Clube esportivo & $400-499$ & G & Mais de 20 anos & Patriarcal \\
\hline B & $\begin{array}{c}\text { Prestação de } \\
\text { serviços }\end{array}$ & $\begin{array}{c}\text { Construção } \\
\text { pesada }\end{array}$ & $900-1000$ & G & $\begin{array}{c}\text { Menos de } 5 \\
\text { anos }\end{array}$ & Híbrida \\
\hline C & $\begin{array}{c}\text { Prestação de } \\
\text { serviços }\end{array}$ & Engenharia & Mais de 1000 & G & Mais de 20 anos & Racional-legal \\
\hline D & $\begin{array}{c}\text { Prestação de } \\
\text { Serviços }\end{array}$ & Saúde & $100-199$ & G & Mais de 20 anos & Patriarcal \\
\hline$E$ & $\begin{array}{c}\text { Prestação de } \\
\text { serviços }\end{array}$ & Hotelaria & $200-399$ & G & De 10 a 15 anos & Carismática \\
\hline $\mathrm{F}$ & Indústria & Alimentícia & $100-199$ & $\mathrm{M}$ & $\begin{array}{c}\text { Menos de } 5 \\
\text { anos }\end{array}$ & Patriarcal \\
\hline G & $\begin{array}{c}\text { Prestação de } \\
\text { serviços }\end{array}$ & Saúde & Mais de 1000 & G & Mais de 20 anos & Racional-legal \\
\hline H & Indústria & Alimentícia & $500-699$ & G & De 5 a 9 anos & Racional-legal \\
\hline
\end{tabular}




\begin{tabular}{|c|c|c|c|c|c|c|}
\hline Codificação & Segmento & Área de Atuação & $\mathrm{N}^{0}$ funcionários & Tamanho & $\begin{array}{l}\text { Tempo de } \\
\text { atuação }\end{array}$ & $\begin{array}{c}\text { Estrutura } \\
\text { política alegada }\end{array}$ \\
\hline 1 & $\begin{array}{c}\text { Prestação de } \\
\text { serviços }\end{array}$ & Geologia & Mais de 1000 & G & Mais de 20 anos & Híbrida \\
\hline$J$ & $\begin{array}{c}\text { Prestação de } \\
\text { Serviços }\end{array}$ & Saúde & $500-699$ & G & Mais de 20 anos & Híbrida \\
\hline K & $\begin{array}{c}\text { Prestação de } \\
\text { Serviços }\end{array}$ & Transporte & Mais de 1000 & G & Mais de 20 anos & Patriarcal \\
\hline L & $\begin{array}{c}\text { Prestação de } \\
\text { Serviços }\end{array}$ & Comércio & 200-399 & G & De 16 a 20 anos & Racional-legal \\
\hline M & Outros & Financeiro & $100-199$ & G & $\begin{array}{c}\text { Menos de } 5 \\
\text { anos }\end{array}$ & Patriarcal \\
\hline $\mathrm{N}$ & Outros & Construção civil & Mais de 1000 & G & Mais de 20 anos & Híbrida \\
\hline 0 & Comércio & Papelaria & $900-1000$ & G & Mais de 20 anos & Racional-legal \\
\hline$P$ & Indústria & Automobilística & Mais de 1000 & G & Mais de 20 anos & Híbrida \\
\hline 0 & Indústria & Alimentícia & Mais de 1000 & G & Mais de 20 anos & Patriarcal \\
\hline $\mathrm{R}$ & $\begin{array}{c}\text { Prestação de } \\
\text { serviços }\end{array}$ & $\begin{array}{l}\text { Tecnologia da } \\
\text { informação }\end{array}$ & $500-699$ & G & Mais de 20 anos & Racional \\
\hline$S$ & $\begin{array}{c}\text { Prestação de } \\
\text { serviços }\end{array}$ & Saúde & Mais de 1000 & G & Mais de 20 anos & Híbrida \\
\hline $\mathrm{T}$ & $\begin{array}{c}\text { Prestação de } \\
\text { serviços }\end{array}$ & Tecnologia & $50-99$ & M & Mais de 20 anos & Híbrida \\
\hline U & $\begin{array}{c}\text { Prestação de } \\
\text { serviços }\end{array}$ & Comércio & $100-199$ & G & De 10 a 15 anos & Racional-legal \\
\hline V & Indústria & Alimentícia & Mais de 1000 & G & Mais de 20 anos & Racional-legal \\
\hline$x$ & $\begin{array}{c}\text { Prestação de } \\
\text { serviços }\end{array}$ & $\begin{array}{l}\text { Locação de } \\
\text { veículos }\end{array}$ & $50-99$ & M & Mais de 20 anos & Hibrida \\
\hline Y & Comércio & Varejista & $200-399$ & G & De 10 a 15 anos & Híbrida \\
\hline Z & Comércio & Varejista & $700-899$ & G & De 10 a 15 anos & Carismática \\
\hline W & Indústria & Siderurgia & Mais de 1000 & G & Mais de 20 anos & Racional-legal \\
\hline
\end{tabular}

Fonte: elaborado pela autora

Em relação ao segmento de atuação das 26 empresas, 53\% são prestadoras de serviços; $23 \%$ são indústrias; $12 \%$ são do comércio e $12 \%$ se definem como atuantes de outros segmentos. Quanto ao número de funcionários existentes, a pesquisa revelou que $38 \%$ delas têm mais de 1.000 - 19\% na Prestação de 
Serviço -, e 15\% contam de 100 a 199. Esses dados estabelecem relação direta com o tempo de fundação da empresa, pois a grande maioria $-65 \%$ delas tem mais de 20 anos de fundação.

Quanto à formação dos responsáveis pela área, 30\% deles são jornalistas; 27\% são das relações públicas e $19 \%$ são formados em publicidade e propaganda. Pode-se perceber também uma preferência por estruturas de comunicação enxutas, pois, debalde o número de funcionários existentes, em $21 \%$ delas há apenas um profissional alocado na área; em 19\% há quatro pessoas; em 12\%, oito e, em outras $12 \%$, apenas dois funcionários. Somente $8 \%$ delas têm mais de 10 funcionários na comunicação.

Para 72\% das empresas, a definição das políticas caberia à cúpula diretiva em conjunto com o setor de comunicação; somente $8 \%$ dos entrevistados dividem esse poder, seja por meio da participação de funcionários e/ou de um Comitê/ Conselho Misto de Representantes. Ou seja, a comunicação continua encastelada em um departamento ou centrada em poucas pessoas, como pode ser visto no gráfico 1.

\section{Gráfico 1 - Pessoas envolvidas na definição das políticas de comunicação}

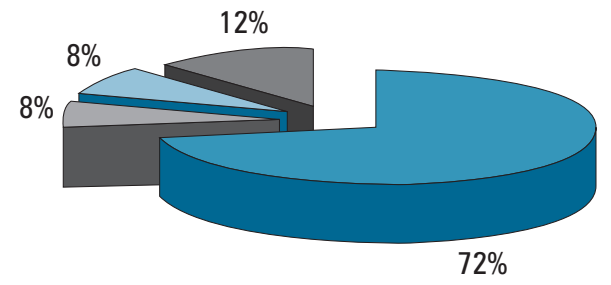

Cúpula Diretiva + Setor de Comunicação

Cúpula Diretiva + Setor de Comunicação + Funcionários

Comitê/Conselho Misto de Representantes

Outros

Em relação à autonomia da área de comunicação, $73 \%$ consideram que é parcial e $27 \%$ alegam ser total. Esses índices apontam que a tão almejada autonomia da comunicação ainda não faz parte da realidade da maioria das empresas, evidenciando o distanciamento entre o discurso e a prática organizacionais. 
Avaliou-se também o quanto organizações e profissionais percebiam a comunicação como capaz de gerar insumos para o negócio. A hipótese era de que, quanto mais envolvimento houvesse, mais a comunicação seria alçada à condição de estratégica, gerando uma "(...) saudável aliança entre a comunicação e o negócio” (FREITAS, 1997, p. 44). Essa participação é total para 31\% dos respondentes, parcial para $57 \%$ e inexistente para $12 \%$.

Os respondentes também apontam a criação de instrumentos de comunicação como atribuição importante e, nesse sentido, jornais institucional/interno/ mural, revistas, folder, produção de vídeos e divulgação por meio de website foram os exemplos citados. Os eventos culturais também tiveram um bom índice de resposta. A comunicação interna aparece em quarto lugar, seguida pela comunicação institucional. $77 \%$ dos entrevistados admitem que algumas atribuições fundamentais do profissional não estariam sendo desenvolvidas.

A comunicação é apontada como um imperativo para o sucesso das organizações, em respostas como:

"Tudo depende da comunicação, a gestão só acontece com a mesma" (Respondente da Empresa E).

"É tudo, tudo é comunicação" (Respondente da empresa O).

O caráter estratégico da comunicação é reforçado por alguns dos responsáveis pelo setor.

"A comunicação é fundamental para a manutenção do clima organizacional da empresa, para que as pessoas possam perceber o que está acontecendo com a empresa, perceber qual o posicionamento estratégico da empresa no mercado" (Respondente da Empresa Z).

Apesar do reconhecimento da importância da comunicação, foram apontados aspectos que indicam certa frustração dos profissionais: faltam o apoio da gestão, a maior qualificação dos profissionais, o incentivo e o envolvimento genuíno do público interno.

"Muito importante, mas não se vê necessidade de aprimoramento. Falta visão de qualificação, incentivo, ser equiparado a qualquer setor importante. Suporte" (Respondente da Empresa Q).

Ao descreverem a infraestrutura e os recursos designados para que bem pudessem realizar seu trabalho, chamou a atenção o fato de os entrevistados prenderem-se a listar os equipamentos disponíveis (computadores, softwares, salas, fax, xerox, TV, vídeo, scanner, celulares corporativos, automóvel etc.). Acesso à literatura especializada, participação em congressos e fóruns especializados, possibilidades de realização de benchmarking, por exemplo, considerados como possibilidades concretas de melhorar práticas, sequer foram aventados. Os recursos humanos não tiveram índice significativo de lembrança, apenas pontuam alguns depoimentos. 
Por outro lado, flexibilidade, dinamismo, criatividade, sensibilidade, bom humor, ética, espírito inovador, curiosidade, paixão, conhecimento, comprometimento, dedicação, adaptação a processos de mudança e agilidade foram os atributos elencados para descrever o perfil ideal do profissional de comunicação, na ótica dos entrevistados. Saber escrever também foi um quesito bastante destacado.

No discurso dos profissionais, a comunicação apresenta-se como estratégica, embora se perceba que, em algumas organizações, esse caráter manifeste-se de maneira mais consistente que em outras, nas quais os aspectos técnico e instrumental ainda prevalecem.

"Estratégico. Porque, quando você está falando de envolver e integrar a administração, a tendência das grandes empresas hoje é essa: fazer uma administração integrada e a comunicação é um canal para isso. É um comunicador que vai criar essas infovias, deixar todo mundo no mesmo nivel de conhecimento dentro da empresa" (Respondente da empresa I).

"Eu acho que é estratégico, porque ele dita a política de ação da empresa. Então, vamos dizer, você tem que fazer mais com menos. Com o minimo de verba $e$ procurar usar nos canais que vão te dar mais retorno (...)." (Respondente da empresa O).

Alguns responsáveis conseguem perceber o papel eminentemente instrumental a ela relegado e reconhecem que seria necessário ampliar a participação da comunicação que, muitas vezes, peca pelo imediatismo.

"Normalmente as empresas tem uma visão de curto prazo da comunicação, então o que acontece, a empresa quer que você resolva o problema imediato então acaba que a comunicação atua no imediatismo, em ações isoladas" (Respondente da empresa B).

Num auto-retrato, os profissionais acham que o termo que melhor define o papel deles na empresa seria realizador para 33\%; em segundo, planejador com $31 \%$ e depois estrategista com $12 \%$.

Em relação aos públicos que seriam considerados como prioritários, percebese uma significativa variação diante da colocação que cada um obteve nesse ranking. Os funcionários, por exemplo, oscilariam entre prioritário e terceiro público mais importante, para 53 e $20 \%$ dos respondentes, respectivamente; em segundo lugar, viriam os clientes, com $20 \%$ dos votos dados; os fornecedores são vistos ora como quarto público mais importante, ora como o quinto (23 e 30\%, respectivamente); como sexto público prioritário, ou seja, o menos importante, viria a comunidade, que recebeu $45 \%$ dos votos nessa colocação. O mais significativo, porém, é o fato de os funcionários passarem a ocupar um lugar menos periférico na visão das empresas. 


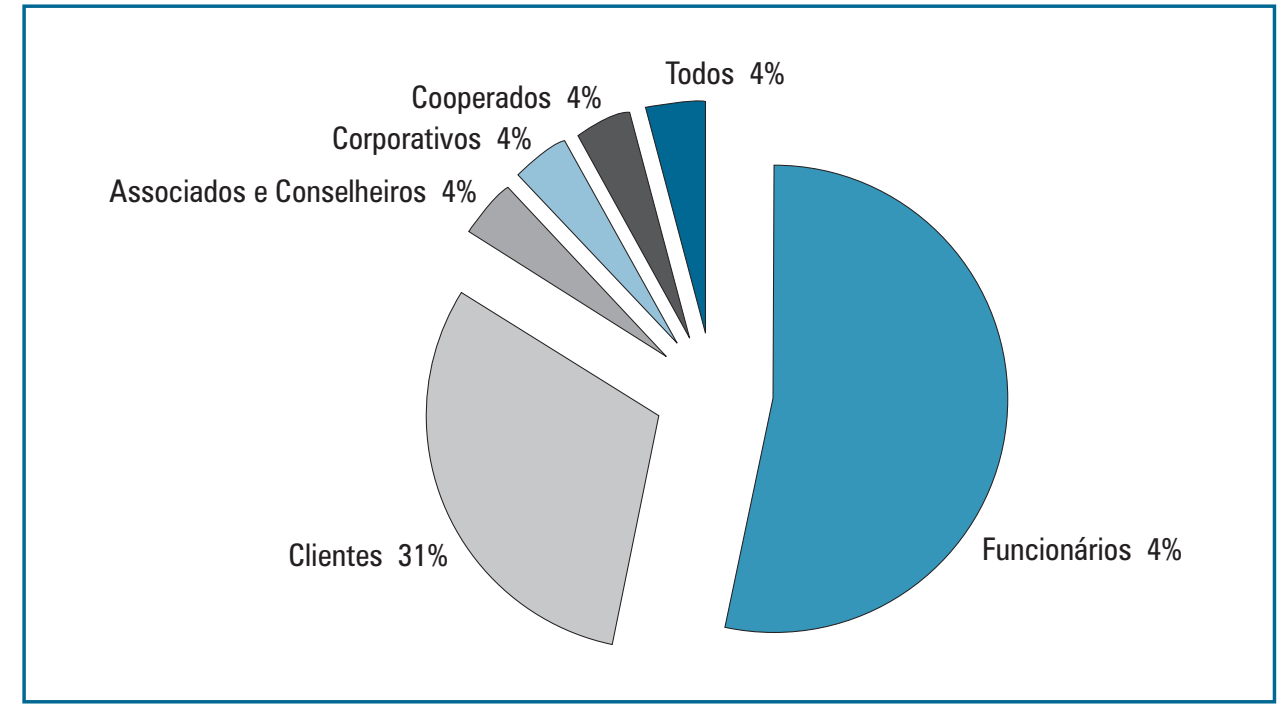

Se uma das questões que este artigo discute se refere à capacidade de resposta do público receptor à mensagem que lhe é disponibilizada, o trabalho de campo dá um fio de Ariadne bastante instigante, pois os profissionais de comunicação revelam que existem mecanismos de avaliação das ações e instrumentos de comunicação, e a participação dos públicos seria ativa. Quando, porém, instados a definir por meio de qual mecanismo esse canal de escuta é estimulado, a maioria das respostas contempla instrumentos tradicionais de comunicação, criados e/ou mantidos pela própria organização. As empresas ainda vinculam o feedback de seu público externo ao número de ligações recebidas em suas centrais de atendimento e/ ou ao aumento no volume de vendas gerado, via de regra, por uma exposição maior na mídia impressa ou televisiva. Não houve nenhum caso em que o respondente falasse a respeito de uma estratégia planejada para capturar a efetividade da relação estabelecida com o público externo. Todavia, as organizações alegam que conseguem mensurar esse retorno por meio desses feedbacks, embora pontuais e bastante informais.

"Bom, a resposta é dos nossos clientes, eles respondem a partir dos veículos de comunicação disponibilizados. Tem uma avaliação com o cliente, sendo uma oportunidade de melhoria para eles." (Respondente da empresa R).

"De fato, o retorno é baixo. A gente tem retorno de anúncios, porque são em mídias especializadas. Mas nós não temos nenhum instrumento para medir, a não ser através do Fale Conosco de nosso site" (Respondente da empresa B).

1 Chama atenção o fato de o profissional não perceber o canal de escuta como possibilidade de ajuste dos processos (grifo nosso). 
A avaliação da comunicação escrita foi apontada como eficaz por $77 \%$ das empresas; como muito eficaz por $19 \%$ e como ineficaz por $4 \%$. Dos instrumentos escritos de comunicação interna, os mais utilizados são: quadro mural, com $25 \%$; jornal, com $18 \%$ e caixa de sugestões, com $15 \%$. Dos instrumentos orais, $26 \%$ elegeram o diálogo como o mais utilizado; seguido pelo telefone e a palestra, empatados em segundo lugar, com a preferência de $25 \%$ dos entrevistados e, em terceiro, a reunião, com 24\%. Em relação aos audiovisuais/digitais, $43 \%$ utilizam a intranet, $22 \%$ o jornal virtual e $20 \%$, os vídeos.

A comunicação oral é definida como muito importante para a maioria. No entanto, a dificuldade em se monitorar e/ou controlar o que é dito também é apontada. O papel do gestor no repasse das informações, principalmente em reuniões, é considerado determinante para o processo, pois é fonte fidedigna, que torna crível o repasse das informações. O e-mail é visto como um empecilho à oralidade, e o telefone foi listado como o mais rápido e com menor chance de gerar ruídos na comunicação.

Em relação aos desafios enfrentados pela comunicação na empresa, os profissionais admitem que são muitos. Observa-se que, para alguns, a comunicação deve conseguir transmitir informações a todos os públicos, demarcando uma preocupação com os ruídos, a homogeneidade e a eficácia.

"Compreensão correta da informação. Quebrar a barreira dos ruidos, muito dificil se colocar no lugar da pessoa de quem recebe a comunicação. Se manter atualizado, informações em fluxo contínuo, evolução rápida" (Respondente da empresa U).

"É a pureza de a informação chegar de forma tanto para a mente quanto no coração das pessoas, que eu acho que a comunicação quando ela consegue inserir a verdadeira missão da empresa para os funcionários, ela realmente conseguiu o objetivo dela. Que não adianta você comunicar todas as normas, todas as regras, qual é a sua missão e tudo, se isso chegou e saiu. Quando insere realmente na alma, no coração do funcionário você pode ter certeza que conseguiu uma comunicação eficaz" (Respondente da empresa L).

Há que se observar, porém, que alguns destacam que o maior desafio se vincula a uma mudança conceitual, que passaria pela capacidade estratégica de a comunicação apresentar-se não apenas como transmissora de informações para os públicos, mas como capaz de envolvê-los com os objetivos da organização.

Perguntados se a comunicação seria utilizada para transmitir informações aos públicos ou se para dialogar com eles, as respostas, mais uma vez, revelam a dualidade percebida na comunicação organizacional hoje. Segundo eles, a comunicação é utilizada tanto para transmitir informações quanto para dialogar com os públicos, pois deve se configurar como uma via de mão dupla. Uma parte significativa dos entrevistados reforça o caráter dialógico 
da comunicação, enfatizando que seu papel não é apenas transmitir informações, mas assegurar a participação dos públicos. Muitas vezes, porém, o que é apontado como diálogo é demarcado apenas pela existência de canais considerados interativos para sugestão e retorno dos públicos. Como se sabe, a participação efetiva não se dá apenas mediante a obtenção do feedba$c k$. Alguns entrevistados admitem que, embora a comunicação deva ser mais aberta, seu caráter ainda é eminentemente instrumental, demarcando a linearidade e o fluxo descendente da comunicação. Há um reconhecimento de que o processo vivido por algumas organizações ainda prioriza o lado mais instrumental, mas já sinaliza esforços para assegurar um maior envolvimento e participação dos públicos.

"Eu não sou muito favorável ao discurso não. Porque o discurso é via de mão única, a pessoa não tem oportunidade de questionar, de fazer a parte dela, entendeu? Então, a forma discursiva é autoritária. Falta muita coragem nas pessoas para falarem o que realmente sentem. Eu acho que a gente tem que incentivar mais o debate, o questionamento" (Respondente da empresa $\mathrm{O}$ ).

Perguntados se o discurso existente na empresa contribuiria para transformar a ação dos sujeitos, algumas respostas surpreendem. Para este trabalho, parece prudente evocar a racionalidade nelas presente.

"Sim, se for pensar pelo lado de diálogo, sim. Pois nossa empresa não faz só o discurso. Há uma preocupação com resposta, relação, participação. Isso faz com que a transformação dos sujeitos aconteça. O discurso, por si só, não faz isso" (Respondente da empresa V).

"Não adianta nada você ter um discurso e não ter atitude. Então eu acho que se o discurso da diretoria for desligado das próprias atitudes, das próprias diretrizes da empresa, não vai funcionar" (Respondente da empresa I).

\section{Conclusão}

Ao submeter os resultados da realidade empírica ao que se postula na fundamentação teórica percorrida, deve-se fazer a seguinte consideração: a amostra avaliada não permite dizer, com rigorosa precisão, como se configura a comunicação organizacional em grandes e médias empresas de Belo Horizonte. Ao longo da análise, no entanto, algumas inferências já se revelam:

- comunicação organizacional fragmentada não contribuindo para os objetivos organizacionais;

- superficialidade na definição dos processos;

- comportamento profissional absolutamente reativo;

- fragilidade teórica latente e desconhecimento das discussões mais recentes do campo da comunicação;

- respostas imaturas ou amparadas em conceitos já considerados obsoletos pela área. 
A análise dos dados permite afirmar que, nas empresas belorizontinas pesquisadas, de maneira geral, a comunicação organizacional padece do que aqui se chamará crise identitária: os profissionais ainda não conseguem compreender a amplitude potencial de uma abordagem mais sistêmica da comunicação. Fragmentada, a comunicação organizacional não se apresentaria como capaz de contribuir para os objetivos organizacionais. A percepção que se tem, ao analisar as respostas obtidas, é que há uma consensual superficialidade para estabelecer as diretrizes comunicacionais: não há uma sistemática para o diagnóstico, as decisões são tomadas de acordo com as demandas percebidas em sondagens bastante informais com os clientes ou quando se percebe uma queda nos resultados financeiros e, posteriormente, não foram listados, de forma consistente, mecanismos para a monitoração e a avaliação da eficácia das políticas de comunicação adotadas. Há uma grande preocupação com o cliente/ consumidor, mas, paradoxalmente, quase nenhuma política de comunicação com ele. Os canais utilizados são os mais tradicionais possíveis, tendo chamado a atenção o uso destacado de caixa de sugestões e o jornal impresso na maioria das empresas pesquisadas. A tão propalada mediação tecnológica se circunscreveria à manutenção de um website.

Por outro lado, observou-se um avanço em relação à adoção de práticas de comunicação organizacional integrada, embora não homogêneo e nem contínuo. As práticas evidenciam uma mudança do meramente informacional para outra, um pouco mais relacional. No entanto, ainda existe forte ênfase no instrumental, como se a simples existência de instrumentos de comunicação fossem, per se, condição para a promoção do diálogo e da participação. Em algumas empresas, o discurso dominante é construído sobre a justificação de que a comunicação é tudo. No entanto, Braga (2001, p. 14) diz que “(...) a comunicação, espalhando-se como objeto por todas as áreas, estando em todas as pautas, não está em nenhum lugar". Talvez seja chegado o momento de se definir, com muita clareza, o que, em uma empresa, pode ser objeto da comunicação organizacional e o que está fora de sua competência. Ao promover o que Braga (2001) chama de desentranhamento, de definir-se o que é por aquilo que, decididamente, não seria comunicação, talvez se pudesse ter, de fato, maior probabilidade de acertar. O que esta pesquisa parece mostrar é que o profissional chama para si a responsabilidade do que quer que seja dentro da organização. E, talvez, o que as empresas precisem é de um profissional que possa lhes dizer, explicitamente, o que há de comunicacional em suas demandas.

Assim, o que se diz, à guisa de conclusão, é que a comunicação organizacional precisa ainda ser objeto de múltiplos estudos, que gerem uma produção acadêmica relevante e, mais do que isso, que os resultados dessa busca sejam discutidos com os diretores e coordenadores de cursos de Comunicação das escolas, apresentados em fóruns estudantis, que permitam uma consciência mais reflexiva, tanto dos profissionais quanto dos que ainda estão em formação. Esse parece ser o grande desafio para a Comunicação Organizacional hoje. 


\section{Referências}

BOHM, D. Diálogo: comunicação e redes de convivência. São Paulo: Palas Athena, 2005.

BRAGA, J. L. Constituição do campo da comunicação. In: COHN, G. et al (Orgs.). Campo da Comunicação: caracterização, problematizações e perspectivas. João Pessoa: Ed. Universitária, 2001.

. Os estudos de interface como espaço de construção do campo da comunicação. Contracampo, n.10/11, p. 219-35, fev. 2004.

CITELLI, A. Comunicação e educação: a linguagem em movimento. São Paulo: Senac, 2004.

CURVELLO, J. J. A. Estudos de comunicação organizacional: entre a análise e a prescrição. INTERCOM, 2002, Salvador. Anais... Salvador, 2002.

FREITAS, S. G. Cultura organizacional e comunicação. In: KUNSCH, M. M. K. (Org.). Obtendo resultados com relações públicas. São Paulo: Pioneira, 1997.

GIRARDI, A. 0. Palavras do presidente: retrato 3x4 da organização. INTERCOM, 2002, Belo Horizonte. Anais... Belo Horizonte: PUC-MG, 2003.

GRUNIG, J. E. Excellence in public relations and communication management. New Jersey: Erlbaum, 1992.

HABERMAS, J. Consciência moral e o agir comunicativo. Rio de Janeiro: Tempo Brasileiro, 1989.

HALL, R. H. Organizações: estrutura e processos. Rio de Janeiro: Prentice-Hall, 1984.

KUNSCH, M. M. K. Planejamento de relações públicas na comunicação integrada. São Paulo: Summus, 1986. . Comunicação organizacional: conceitos e dimensões dos estudos e das práticas. In: MARCHIORI, M. (Org.). Faces da cultura e comunicação organizacional. São Paulo: Difusão, 2006.

MARTINO, L. C. História e identidade: apontamentos epistemológicos sobre a fundação e fundamentação do campo comunicacional. Revista E-Compós, dez. 2004

NASSAR, P. Tudo é comunicação. São Paulo: Lazuli, s.d.

OLIVEIRA, I. de L.; PAULA, M. A. de. 0 que é comunicação estratégica nas organizações? São Paulo: Paulus, 2007.

OLIVEIRA, I. de L. Dimensão estratégica da comunicação no contexto organizacional contemporâneo: um paradigma de interação comunicacional dialógica. Tese (Doutorado em Comunicação) - Escola de Comunicação. Rio de Janeiro: Universidade Federal do Rio de Janeiro, 2002.

PAULINO, R. A. F. A comunicação no mundo do trabalho: da racionalidade comunicativa à racionalidade do consumo. INTERCOM, 2002, Belo Horizonte. Anais... Belo Horizonte: PUC-MG, 2003.

QUERÉ, L. D'un modèle épistémologique de la communication à un modèle praxeologique. Réseaux, Paris, n.46-47, 1991.

REIS, M. C. Mudança organizacional, comunicação, criatividade e inovação. In: MARCHIORI, M. (Org.). Faces da cultura e comunicação organizacional. São Paulo: Difusão, 2006.

RUSCHEINSKY, A. Metamorfoses da cidadania. São Leopoldo: UNISINOS, 1999.

SOARES, A. T. N. Constituição teórica do campo da comunicação organizacional - Uma contribuição da realidade empírica. I ABRAPCORP, 2006. São Paulo: Anais... São Paulo: ECA/USP, 2006.

WOLTON, D. É preciso salvar a comunicação. São Paulo: Paulus, 2006. 